\title{
Development and Evaluation of the Efficiency of In-service Training Program with the Theme of Peace Education
}

\author{
Semra Demir Başaran ${ }^{1, *}$, Sevgi Özden Karakurt ${ }^{2}$ \\ ${ }^{1}$ Department of Educational Sciences, Faculty of Education, Erciyes University, Kayseri, Turkey \\ ${ }^{2}$ Ministry of Education, Şehit Serkan Ciddioğlu Primary School, Kayseri, Turkey
}

Copyright $\subset 2017$ by authors, all rights reserved. Authors agree that this article remains permanently open access under the terms of the Creative Commons Attribution License 4.0 International License

\begin{abstract}
In this article, an in-service training program was developed and evaluated to improve the peace education competencies of primary school teachers. This program, named as In-Service Training Program with the Theme of Peace Education for Primary Teachers (BEHEP), was based on the system approach. The implementation was completed in 28 hours with the participation of 18 primary school teachers working in Serkan Ciddioğlu Primary School located in Melikgazi district of Kayseri province. The article was designed according to the mixed research model. Interview forms, concept forms, course plans, participant diaries and in-service training evaluation scales were used as data collection tools. Qualitative data were analyzed via content analysis method; quantitative data were analyzed via SPSS. BEHEP has been an effective program to raise the awareness of teachers and to improve their skills in designing learning environments suitable for peace education.
\end{abstract}

Keywords Peace Education, Primary School Teachers, In-service Training, Curriculum

\section{Introduction}

Recent statistical data have shown that violence based crime rate among children aged 18 or younger is on the increase [1]. The increase in the number of children showing tendency to committing crime and involving in violence is increasing which indicates that education given in primary schools is not effective enough to make students acquire peaceful behaviors.

However, educating peaceful individuals and ensuring a peace culture depend heavily on the education given in primary school education. To Türnüklü [2] the best way to eliminate the destructive conflict tradition is to particularly concentrate on development processes of students in pre-school and primary school periods. K1zmaz [3] asserts that efforts to prevent violent behaviors should be intensified particularly in childhood period. Therefore, peace education should be implemented in schools from the early ages [4].

Peace education refers to the process of promoting the knowledge, skills, attitudes and values needed to bring about behavior changes that will enable children, youth and adults to prevent conflict and violence, both overt and structural; to resolve conflict peacefully; and to create the conditions conducive to peace, whether at an intrapersonal, interpersonal, intergroup, national or international level [5]. Such an education is believed to help students develop violence handling skills for individual, national and international conflicts, decrease their tendency to violence, encourage them to instill respect for human rights and peace [6-7].

For an effective and efficient peace education, setting each element of education process to work is vital. The most important one of these elements is undoubtedly teacher competencies regarding peace education because they are the practitioners of peace education [8]. Teachers to give peace education are expected to make students aware of peace, adopt a peace consciousness, informed about peace strategies, develop skills for positive relationships and comprehend the threats of wars [9]. In this sense, the responsibility of teachers regarding peace education can be listed as creating a democratic classroom environment, teaching cooperation, developing moral sensitivity and critical thinking skills and strengthening self-respect [10]. Johnson and Johnson [11-12] stated that students should be equipped with basic values such as respect for efforts and ideas of other people, holistic relationship with people, and empathy and peaceful conflict resolution skills.

Demir [13] set out from the element of teacher competencies for an efficient peace education and conducted a study exploring the views of primary school teachers on peace education in the context of problems, expectation and recommendations. She concluded that teachers do not have 
the necessary knowledge, skills and awareness regarding peace education. Teachers, whose views were explored within the scope of the study, highlighted the fact that they are not competent enough for peace education and they need to be trained about this issue. Moreover, majority of teachers agreed that this training should not be theoretical but practical. Results of this study indicated that primary school teachers are eager to participate in any training activities regarding peace education. The article conducted by Demir [13] revealed that descriptive studies on peace education in Turkey are limited. Thus, this article functions as needs analysis since it revealed the needs for peace education.

Professional knowledge, skills, attitudes and habits, whose deficiencies are proved, are provided by in-service training activities [14]. To Dori and Herscovitz [15]; in-service trainings keep the teachers away from the mindset of conveying information and help them adopt new and student-centered approaches. An effective in-service training program needs to be based on teachers' needs, provide content specified in accordance with the objectives with mainly practice and have evaluative studies at the end of the training [16-17-18]. It is possible that in-service trainings with such qualities will contribute positively to teachers' personal and professional improvements [19].

Purpose of this article is to reveal whether In-Service Training Program with the Theme of Peace Education for Primary Teachers (BEHEP), which was designed according to peace education needs of primary school teachers, is effective in enhancing primary school teachers' competencies regarding peace education. The aim of the developed training program is to create an awareness in primary school teachers regarding peace education and enhance their knowledge and skills in relevant terms.

To this end, questions below were tried to be answered:

1. Is BEHEP efficient in enhancing concept knowledge of primary school teachers regarding peace education?

2. Is BEHEP efficient for primary school teachers in designing classroom environments appropriate for peace education?

3. What are the views of primary school teachers on implementation process of BEHEP?

4. What are the recommendations and expectations of primary school teachers regarding BEHEP?

\section{Method}

\subsection{Research Model}

Mixed research model with dominant/non-dominant research design was employed in this study. Qualitative research method was prioritized in the study and quantitative data were used to support qualitative data.

\subsection{Study Group}

Study group covers 18 primary school teachers working in Şehit Astsubay Serkan Ciddioğlu Primary School in Kayseri province during 2013-2014 academic year. The school was selected mostly because the district where the school is allowing migrants constantly. Therefore, the school has a variety of student profiles which increases the possibility of conflicts and disagreements. Moreover, primary school teachers' working in the school participation in SWOT analysis is important to meet the revealed needs of teachers regarding this issue.

\subsection{Data Collection Tools}

Five different data collection tools were used in the article.

Interview Form: Semi-structured interview method, one of the qualitative research methods, was employed in this study. Semi-structured interview form covered fourteen questions prepared by the researcher. Internal validity of the scale was ensured by faculty members working in Faculty of Education in Erciyes University. After receiving the views of participants following pilot study, interview form was finalized

Peace Education Concept Form: Peace Education Concept Form was developed in order to determine the influence of BEHEP implementation on conceptual knowledge of participants. This process was finalized through the following phases; (1) creating a concept pool regarding peace education, (2) evaluating the concepts with three field experts in terms of relatedness and comprehensiveness, (3) excluding certain concepts and (4) finalizing the form covering seven concepts.

Participant Diaries: Participants were made to record their views on BEHEP activities at the end of each practice day. These are (1) Course Plans; following BEHEP, each participant was asked to prepare a course plan to reveal important clues concerning their conceptual comprehension levels and how they will convey what they have learnt to students, (2) In-Service Training Evaluation Scale; quantitative data of the study were obtained via In-Service Training Programs Evaluation Scale developed by Tekin and Yaman [20]. The scale has two dimensions and 28 items. It is a five point Likert type scale with Cronbach Alpha value of 0.940. The scale was named as BEHEP Evaluation Scale in the study).

\subsection{Data Collection Process}

System model was employed in BEHEP development study. System approach model covers analysis, design, development, implementation and evaluation phases [21-17-22-23-24]. Study process is given hierarchically below.

\subsubsection{Needs Analysis}

SWOT and document analyses, which were two of needs analysis methods, were employed for needs analysis phase of the study. In order to reveal primary school teachers' needs regarding peace education, a meeting was held with 18 teachers on $15^{\text {th }}$ of April in 2013. SWOT analysis and its purposes were explained. The form, which was designed for 
teachers to write weak and strong situations, opportunities and risks while designing learning environments appropriate for peace education, was presented to teachers. Data were analyzed through descriptive analysis. According to teachers, strong aspects were patience, compassion, awareness on responsibilities, being against violence and experience. On the other hand, weak aspects were considered as having no time to improve themselves, being dependent on their habits, and lack of methodological and technical knowledge regarding constructivism. The difficulties which were thought to be encountered in practicing peace education were advanced ages which prevent learn new things, deficiency in teaching materials, limited time due to intensity of the curricula, communication gap between parents and teachers and financial conditions. Opportunities were expressed as being experienced, support of school management and internet. Risks were expressed as not being able to complete the content of curricula, the absence of peace education in curricula, and negative expressions of inspection organs (inspector).

In the review conducted within the scope of document analysis, it was seen that program development studies focusing on peace education in Turkey were generally devoted to students. In this sense, the article conducted by Demir [13] functions as a needs analysis for this study because it dwells on problems, expectation and recommendations of primary school teachers regarding peace education. In addition, peace education implementations addressing to teachers in other countries were analyzed [25-26-27].

\subsubsection{Design}

BEHEP design covers four phases: The first phase deals with program objectives taking into account the needs which were revealed as a result of needs analysis. The Second phase deals with content arrangement studies within the scope of general objectives of the program. In this sense, a literature review was conducted. It was seen that Peace Education Program Model (PEP) produced in Kester's [28] study, approaching peace education with five learning modules, is an appropriate approach to meet the needs of primary school teachers regarding peace education. The third phase deals with exploring which teaching model can be effective in implementing in-service training programs [22-21-23-29-26-30-27] and teaching experiences which will make teachers acquire objective behaviors determined for the end of the implementation. The fourth phase deals with time schedule specifying the dates, place, and hours for implementation to take place as well as notifying teachers on these issues.

\subsubsection{Development}

Program and measurement tools were prepared for BEHEP's pilot study. Stationary materials which to be used for practices, refreshments and drinks to be served during the intervals between sessions were supplied, and all the tools, instruments and materials were procured.

\section{Implementation}

1. Pilot Study: It is necessary to conduct a pilot study on a sample group similar to the actual sample group before conducting the main implementation. Thus, deficiencies of the program can be detected and necessary precautions are taken, and the program is finalized [23]. In this sense, a pilot study regarding BEHEP was conducted in Demir Karamanc1 Primary School in Melikgazi district of Kayseri province between the dates 24 June 2013 and 28 June 2013 when 2013-2014 academic year summer term seminars were being held. 19 primary school teachers participated in the study. 11 of them were females while 8 were males. The pilot study took 25 hours to complete. During the course of implementation, the researcher took observation notes to reveal the deficiencies of the program and whether the implementation was efficient or not. Moreover, the deficiencies of concept form, interview questions, participant diaries, course plans and BEHEP evaluation scale were detected. In this sense, some decisions were made to change the implementation date, add or exclude certain activities for certain modules, prefer interview method instead of focus group method and to modify certain interview questions.

2. Main Implementation: The main BEHEP implementation took place between the dates 09 September 2013 and 18 September 2013 in Şehit Piyade Astsubay Serkan Ciddioğlu Primary School in Melikgazi district of Kayseri province. 18 primary school teachers participated in the study. The implementation was completed in 28 hours. The implementation involved the modules constituting the content [1) Peace Module, 2) Violence and Alternatives Module, 3) Media and Peace Module, 4) Human Rights from A Gender Perspective Module, 5) Decision and Conflict Approaches in Teaching Module] and activities which were mainly based on cooperation because "team supported individualization" method was employed for the activities. Moreover, the process was ensured to be dynamic by setting learning process into work and relying on group interaction, cooperation and individual activities. Sitting plan was changed constantly in accordance with the activities. Groups of two, three and four were formed taking into account the quality of the activities. After completing 28-hour implementation process, participants were asked to express their knowledge and views regarding the efficiency of the program.

\subsubsection{Evaluation}

In order to evaluate BEHEP's efficiency, qualitative and quantitative data were used.

\section{Data Analysis}

1.1. Qualitative Data Analysis: Content analysis method was employed to analyze the data obtained through qualitative data collection tools in the study. (1) Content analysis of peace education concept form was carried out by adding and changing certain codes in the code list which was created taking into account conceptual framework of peace 
education. (2) Analysis of interview records involves transcription of the recorded interviews by the researcher-participant respectively on interview documentation form. Member inspection was employed to raise internal validity and reliability of the study. (3) Analysis of participants' diaries covers detailed and repetitive reading of the diaries by the researcher and marking the significant sections to form codes, themes and sub-themes. (4) Course plans were analyzed formally according to the sample course plan for primary school curricula prepared by MEB. Contextually, they were analyzed taking into account peace education literature.

1.2. Quantitative Data Analysis: Data obtained through BEHEP Evaluation Scale were analyzed by arithmetic mean technique. Arithmetic mean ranges which lay the basis for Likert type scale are as follows: "1.00-1.80=I definitely do not agree", "1.81-2.60=I do not agree", "2.61-3.40=I am hesitant", "3.41-4.20=I agree" and "4.21-5.00=I definitely agree".

Table 1. Conceptual knowledge of participants regarding peace education both before and after BEHEP

\begin{tabular}{|c|c|c|c|c|c|c|c|c|}
\hline \multirow{2}{*}{$\begin{array}{c}\text { Implementation } \\
\text { Time }\end{array}$} & Peace & Violence & Conflict & $\begin{array}{c}\text { Peace } \\
\text { Culture }\end{array}$ & $\begin{array}{c}\text { Peaceful } \\
\text { Individual }\end{array}$ & $\begin{array}{c}\text { Peaceful } \\
\text { Teacher }\end{array}$ & $\begin{array}{c}\text { Peaceful Teaching } \\
\text { strategies }\end{array}$ & \begin{tabular}{c} 
Total \\
\cline { 2 - 8 }
\end{tabular} \\
\hline Before BEHEP & 115 & 110 & 67 & 48 & 27 & 33 & 427 \\
\hline After BEHEP & 244 & 168 & 149 & 118 & 97 & 92 & 977 \\
\hline Difference & 129 & 58 & 82 & 70 & 70 & 59 & 82 & 550 \\
\hline
\end{tabular}

\section{Findings Obtained from Interviews:}

Table 2. Findings regarding the themes derived from the interviews

\begin{tabular}{|c|c|c|}
\hline Table 2. Findings regarding the themes derived from the interviews \\
\hline Themes & F & 230 \\
\hline Peace & 203 & 19,25 \\
\hline Violence & 167 & 16,98 \\
\hline Conflict & 150 & 13,98 \\
\hline Peace culture & 143 & 12,55 \\
\hline Peaceful individual & 144 & 11,96 \\
\hline Peaceful teacher & 158 & 12,06 \\
\hline Peaceful teaching strategies & 1195 & 13,22 \\
\hline Total & 100 \\
\hline
\end{tabular}

Table 2 shows content analysis results of interviews conducted with primary school teachers to reveal their views on peace education after the implementation.

\section{Findings}

The sequence specified in the sub-purposes of the study was implemented for the presentation of the findings. There are four sections of findings.

\subsection{Findings Regarding the First Sub-Problem}

1. Findings Obtained from Peace Education Concept Form: Peace education concept forms were implemented twice, both before and after the implementation, in order to reveal the change in participants' knowledge of BEHEP. Table 1 shows the relevant analysis results.

Considering Table 1, it was seen that frequencies regarding concept definitions increased after BEHEP implementation. When the difference values were examined, it was seen that values corresponding to each concept were positive. This indicates that the education given was efficient to enhance peace education concept knowledge of teachers.

\section{Findings Obtained from lnterviews:} education after the implementation. 
It was seen that the concept which was expressed most frequently was peace. Moreover, it was noteworthy that in interview codes, peace was referred to as a multi-dimensional and comprehensive concept covering a wide variety of things as well as absence of violence or war. The view of K3, "I learnt that there are two types of peace, which are active and passive, and also, there is personal peace which is about the individual himself", explains this situation. In relation to violence, $\mathrm{K} 7$ stated that "the students in the class of a violent teacher are in a constant state of terror; they would not want to participate in the activities to not make mistakes" taking into account the learning environment which explains the influence of violence on learning environment. The opinion frequently expressed by the participants concerning conflict was that there were not only negative conflicts but also the positive ones. K2 stated that, "I used to think that conflict refers to something negative all the time, however, I learnt that it has positive versions as well". In relation to peace culture, K5 stated "as far as I understand, the purpose of peace education is to create a peace culture which can last for years". K14 expressed peaceful individual: "A peaceful individual has to be fair and to support equality." On peaceful teacher, K12 stated professional characteristics of a peaceful teacher by saying, "a peaceful teacher should encourage both students and parents for peace and prevent violence". The concept of peaceful teaching strategies was explained taking into account preparation, practice and evaluation dimensions of teaching process. For instance, K7 drew the attention to preparation by saying, "In order to create a peace environment in the class, the teacher should be prepared in such a way that s/he draws the attention of each student"; K3 expressed his/her opinions on implementation by stating, "I realized that group work is the most common method, I can say that this method is indispensable for peace education". Evaluation was explained by K4 with the following statement: "I reckon that the new constructivist system is similar to peace education. For instance, we assign in-course performance and other performance projects. It is quite similar to peace education as far as I can see".

\subsection{Findings Regarding the Second Sub-Problem}

1. Findings Obtained from Interviews: Opinions regarding BEHEP's influence on creating and designing learning environments appropriate for peace education were categorized under two themes which are development of awareness and qualities.

Findings indicated that teachers did not consider their knowledge levels regarding peace education adequate and the education given was influential in raising their awareness levels regarding the peace education. For instance, K14 stated, "I thought peace education was for countries experiencing war, now I know that it should be integrated into all classes and courses." K11 denoted that "the education was not for teaching theoretically" and they learnt how to intervene in conflicts within the class and to raise people believing in peace.

Views regarding the influence on enhancing qualities focus on internalizing peace, developing positive thoughts on a sustainable peace culture within society, developing educational skills and bringing peaceful teacher qualities. K5 tried to explain this influence with the following statement: "I cannot say that I thoroughly internalize peace, however, I can criticize myself and realize my deficiencies." K17 stated that $\mathrm{s} /$ he experience a positive change by saying; "I believed that it is really possible to educate peaceful individuals during the activities." K7: "We employed methods whose names were familiar but never had I used them in the class before." K16: "Only on the first day we had lectures traditionally, then we used various methods, I can use them in the class." K11: "I made progress to be a peaceful teacher." All of these statements revealed that BEHEP was influential in designing education environments suitable for peace education.

2. Findings Obtained from Diaries: Primary school teachers made daily records in diaries regarding BEHEP which reveal the learning statuses. Based on the diaries, it was seen that peace education is associated with knowledge, skills and values. K3's expressions, which were taken from diary, are as follows: "Today, I learnt that peace does not only refer to absence of war. Being only silent and accepting things should not be considered as the real peace, which really makes sense." (K3, 07 September 2013). Some of the participants emphasized the fact that the education they received contributed to their skills of resolving conflicts, controlling anger and effective communication. K1 stated, "Today, we tried to control the anger and being calm at that time. It would be really nice if I could practice it in the class" (K1, 16 September 2013). Another area of acquisition, which was noteworthy in teachers' diaries, was covering values such as empathy, gender equality, justice and tolerance. In this sense, K2 expressed the following statement: "The activity regarding female-male was really nice today. We discussed whether we make a discrimination among students on behalf of a certain gender. I realized that it is really important to pay attention to each statement and behavior when I am in the class now" (K2, 12 September 2013).

3. Findings Obtained from the Course Plans: In order to analyze course plans, sample course plan, which can be found in Ministry of National Education's Curricula was taken into account. Accordingly, a peace education course plan evaluation form was prepared. Formal analysis of course plan is based on sample course plan in the curriculum. Contextual analysis was conducted within the scope of peace education literature. 
Table 3. The appropriateness of course plans prepared by participants to peace education

\begin{tabular}{|c|c|c|c|c|c|c|c|c|c|c|c|c|c|c|c|c|c|c|}
\hline $\begin{array}{c}\text { The } \\
\begin{array}{c}\text { Appropriateness } \\
\text { of Course Plans } \\
\text { Prepared by } \\
\text { Participants to } \\
\text { Peace Education }\end{array}\end{array}$ & $\mathrm{K} 1$ & $\mathrm{~K} 2$ & $\mathrm{~K} 3$ & $\mathrm{~K} 4$ & $\mathrm{~K} 5$ & $\mathrm{~K} 6$ & $\mathrm{~K} 7$ & $\mathrm{~K} 8$ & $\mathrm{~K} 9$ & $\mathrm{~K}$ & $\mathrm{~K}$ & $\mathrm{~K} 12$ & $\mathrm{~K} 13$ & $\mathrm{~K} 14$ & $\mathrm{~K} 15$ & $\mathrm{~K} 16$ & $\mathrm{~K} 17$ & $\mathrm{~K} 18$ \\
\hline $\begin{array}{c}\text { Formal } \\
\text { appropriateness }\end{array}$ & $\mathrm{X}$ & $\mathrm{X}$ & $\mathrm{X}$ & $\mathrm{X}$ & & & $\mathrm{X}$ & & $\mathrm{X}$ & & $\mathrm{X}$ & $\mathrm{X}$ & $\mathrm{X}$ & $\mathrm{X}$ & $\mathrm{X}$ & $\mathrm{X}$ & & $\mathrm{X}$ \\
\hline $\begin{array}{c}\text { Contextual } \\
\text { appropriateness }\end{array}$ & $\mathrm{X}$ & & $\mathrm{X}$ & $\mathrm{X}$ & $\mathrm{X}$ & $\mathrm{X}$ & $\mathrm{X}$ & $\mathrm{X}$ & $\mathrm{X}$ & $\mathrm{X}$ & $\mathrm{X}$ & $\mathrm{X}$ & $\mathrm{X}$ & $\mathrm{X}$ & $\mathrm{X}$ & $\mathrm{X}$ & $\mathrm{X}$ & $\mathrm{X}$ \\
\hline
\end{tabular}

In the analysis of course plans according to peace education, teaching process explained in the plan was handled by having respects for differences, empathy, and rejection of discriminatory attitude and behaviors. In addition, visual materials, discussion method and question-answer technique, the objective of tolerance towards different opinions, emphasis on solidarity through cooperation, encouraging empathy through sample incidents, determination of alternative evaluation methods and acceptance of students with individual differences were effective in analyzing course plans.

Considering Table 3, all the course plans except one were appropriate for peace education contextually. However, certain course plans had formal deficiencies.

\subsection{Findings Regarding the Third Sub-Problem}

1. Findings Obtained from Interviews: Views of primary school teachers regarding BEHEP implementation process cover expressions about implementation date and period of the program, the qualities of the hall where implementation took place, consideration of participant needs and qualifications of the practitioner. Some of the views selected from interview data are as follows: K4; “...it was good to learn something new before a new academic term." K1; ...I did not have transportation difficulties since the program was implemented in our school." K5; "the period was long enough, when it gets longer, the participation decreases."

2. Findings Obtained from Participant Diaries: Participant diaries indicated that teachers evaluated BEHEP process in the context of activities and organization. One of them was K12: "I can practice the activity in today's class in my classes as well. Activities require accessible and inexpensive materials such as cardboards and pencils" (K12, 11 September 2013). This expression emphasizes the practicability of BEHEP activities. K5 stated certain expression in relation to organization of the implementation: "Today, peace education seminar ended. It was not boring as the previous ones which I had attended for years. There were even snacks and drinks for us for the breaks between sessions. I will attend again if similar seminars are held in the future" (K5, 18 September 2013).

3. Findings Obtained from BEHEP Evaluation Scale:

a. BEHEP Evaluation Scale Teaching Process and Acquisitions:

Table 4. Participants' views regarding teaching process and acquisitions

\begin{tabular}{|c|c|c|c|c|c|c|c|c|}
\hline \multirow[b]{2}{*}{ Scale Dimension } & \multirow{2}{*}{$\begin{array}{l}\text { The } \\
\text { Number } \\
\text { of Items }\end{array}$} & \multicolumn{5}{|c|}{ Score Interval } & \multirow{2}{*}{$\begin{array}{l}\text { Arithmetic } \\
\text { Mean }\end{array}$} & \multirow{2}{*}{$\begin{array}{c}\text { Std. } \\
\text { Deviation }\end{array}$} \\
\hline & & $\begin{array}{c}\text { I definitely do } \\
\text { not agree }\end{array}$ & I do not agree & I am hesitant & I agree & $\begin{array}{l}\text { I definitely } \\
\text { agree }\end{array}$ & & \\
\hline $\begin{array}{l}\text { Teaching process } \\
\text { and acquisitions }\end{array}$ & 21 & $21,00-37,80$ & $38,01-54,60$ & $54,81-71,40$ & $71,61-88,20$ & $88,41-105,0$ & 92,05 & 6,71 \\
\hline
\end{tabular}

Arithmetic mean value for participants' views regarding BEHEP teaching process and acquisitions was found $\bar{X}=92.05$ and this value corresponds to "I definitely agree" level. Findings indicate that participants had positive opinions concerning BEHEP teaching process and acquisitions.

b. BEHEP Evaluation Scale Organization Design Dimension:

Table 5. Participant views regarding organization design

\begin{tabular}{|c|c|c|c|c|c|c|c|c|}
\hline \multirow{2}{*}{$\begin{array}{c}\text { Scale } \\
\text { Dimension }\end{array}$} & \multirow{2}{*}{$\begin{array}{c}\text { The Number } \\
\text { of Items }\end{array}$} & $\begin{array}{c}\text { I definitely do } \\
\text { not agree }\end{array}$ & $\begin{array}{c}\text { I do not } \\
\text { agree }\end{array}$ & $\begin{array}{c}\text { I am } \\
\text { hesitant }\end{array}$ & I agree & $\begin{array}{c}\text { I definitely } \\
\text { agree }\end{array}$ & $\begin{array}{c}\text { Arithmetic } \\
\text { Mean }\end{array}$ & $\begin{array}{c}\text { Std. } \\
\text { Deviation }\end{array}$ \\
\hline $\begin{array}{c}\text { Organization } \\
\text { Design }\end{array}$ & 7 & $7,00-12,60$ & $12,67-18,20$ & $18,27-23,80$ & $23,87-29,40$ & $29,47-35,00$ & 31,66 & 2,67 \\
\hline
\end{tabular}


Considering Table 5, arithmetic mean value for organization design of implementation was found $\bar{X}=$ 31.66 and this value corresponds to "I definitely agree" level. Accordingly, BEHEP's date, period and practitioner's qualifications were positively evaluated by the participants.

\subsection{Findings Regarding the Fourth Sub-Problem}

Participants expressed his/her view under the recommendations theme and stated that BEHEP implementation should cover all the primary school teachers. For instance, K9: "this in-service training made me question my habits, each teacher should be trained within the scope of this program." Participants encoded K5, K14 and K17 emphasized the importance of providing peace education in teacher training programs while $\mathrm{K} 1, \mathrm{~K} 3$ and $\mathrm{K} 8$ suggested that peace education should be included in curricula.

\section{Discussion and Conclusions}

The findings indicate that primary school teachers had not had knowledge enough on peace education concepts before BEHEP was implemented. This result is similar to the results of the article conducted by [31] in relation to teacher training. Bjerstedt reported that teachers who were willing to participate in peace education lacked the necessary knowledge. Moreover, Demir [13] stated in her article that primary school teachers did not have the necessary knowledge, skills and awareness regarding peace education. Findings which were obtained after the implementation indicate that concept knowledge level of the participants raised. This result is in line with Marthe's [27] article which concluded that peace education program contributed to knowledge of undergraduate students concerning peace and peace education. On the other hand, Sağkal [32] stated that students in experimental group acquired information on the relevant concepts after a peace education program was implemented.

It was found that BEHEP was effective in creating awareness of participants, whose awareness levels regarding peace education was not high enough, after the training was given. As a matter of fact, Kester [28] stated that it is important to clearly express the meaning and purpose of peace education in case certain educators attaches a political value to it. Another result of the article is that findings which support the claim that BEHEP activities encourage participants to internalize peace are in line with results of similar articles in literature [33-34-27]. This makes it clear that BEHEP is successful in achieving the objectives. On the other hand, activities positively influenced participant views to create a social peace culture. It was found that these activities were motivating as well. This result corresponds to UNESCO's [6] assertion that a sharing culture based on freedom, justice, tolerance and solidarity in society can only be possible through education given within peaceful themes. Furthermore, BEHEP contributed to participants in teaching strategies, methods and techniques as well as alternative evaluation methods. This is because the most commonly employed strategies, methods and techniques in course plans were discovery strategy, cooperative teaching, discussion, case study and dramatization. Staub [35] emphasizes that student centered methods in peace education transform the relations, eliminates the trivialization between individuals or groups, and create an environment in which individuals mind each other's benefits. Bar-Tal, Rosen, and Nets-Zehngut [4]; conducted a article which reported that the attitudes and behaviors that are expected to be acquired by individuals after peace education can only be realized through experimental learning methods. Through BEHEP activities, a progress was observed in primary school teachers' skills of peaceful conflict resolution, realizing the importance of using them and being eager to employ them in the class, controlling anger, and effective communication and listening. These findings are in line with the findings of similar previous articles conducted in relation to peace education [36-37-38-26-39-40-41-42-32-27-43].

Another result derived from findings was that BEHEP activities were considered interesting, participant-oriented and practicable by the participants. Relevant participant views are similar to Sharma's [16] article explaining that it is important to give both theoretical and practical training to teachers so as to ensure employment of these methods within the class and Açıkgöz's [44] article which advocates that in-service trainings should enable participants to be active learners. Participants expressed positive statements on the implementation process and practitioner's qualifications which have an influence on implementation level [45-46]. In addition to practitioner's qualification, the date, period, refreshments served during the breaks were considered appropriate, adequate and positive by the participants. Such elements of the process were stated by Açıkalın[47] Yalın [48]; MEB- EARGED [49]; Gökyer [50] to increase the efficiency of in-service trainings. All in all, BEHEP was considered an education process encouraging active participation, based on active learning, and aiming at experimental learning. BEHEP has aspects similar to various peace education programs held by UNICEF [5].

Participants recommended emphasis on peace education in order to create a social peace culture, peace education studies should cover all the teachers. To them, peace education programs should be included in the curricula of institutions training teachers, and peace education should be given as a separate course in curricula. Taking into account peace education literature, many researchers emphasized the importance of similar elements [8-51-5-25-10-52-53-26-39-2-42-54-55-56-57-13-58-32-5960-61-62].

Article results demonstrated that BEHEP is an effective program to raise awareness levels of primary school teachers regarding peace education and enhancing their knowledge skills to design learning environments suitable for peace education. Based on the relevant results, recommendations can be listed as follows: peace education should be 
integrated into curricula, trainings should be given to enhance proficiencies and competencies of all classroom and branch teachers as well as pre-service teachers, participation in such trainings should be encouraged, and students should be made to adopt peace values.

\section{Acknowledgement}

This work was supported by the [ ErciyesUniversity Scientific Researchs Project Department] under Grant [4211].

\section{REFERENCES}

[1] Turkish Statistical Institute. Prisons Statistics. 2013

[2] Türnüklü, A. Restorative Discipline and School Class A Contemporary Approach to Discipline. Ekinoks. Ankara: 2006

[3] Kizmaz, Z. A Theoretical Approach to the Roots of Violence Behaviors at Schools. C.U. Journal of Social Science 30(1): 47-70. 2006.

[4] Bar-Tal D., Y. Rosen, and R. Nets-Zehngut. Peace education in societies involved in intractable conflicts: Goals, conditions, and directions. In Handbook on Peace Education, edited By G. Salomon, and E. Cairns, 21-43. New York: Psychology Press. 2010.

[5] Fountain, S. Peace Education In UNICEF, UNICEF Staff Working Papers. Working Paper Education Section Programme Division UNICEF. New York: PDED. 1999.

[6] United Nations Educational Scientific and Cultural Organization. Framework For Teachers. India: New Delhi. 2005.

[7] Ekpoh, U. I. Assessing The Institutionalization Of Peace Education And Peace Culture At Post Primary School Level In Calabar Education Zone, Cross River State, Nigeria. International Journal of Education and Research 3(7): 175-182. 2015.

[8] Reardon, B. Education For Global Responsibility: Teacher Designed Curricula For Peace. New York: Teachers College Press. 1988.

[9] Harris, I. Evaluating Peace Education. Paper presented at the Annual Meeting Of American Educational Research Association, Chicago, June, 21-25. 2003.

[10] Harris, I., and M. Morrison. Peace education (2nd ed.). Jefferson, NC: McFarland. 2003.

[11] Johnson, D., and R. Johnson. Essential Components Of Peace Education. Theory Into Practice 44(4): 280-292. 2005b.

[12] Johnson, D., and R. Johnson. Peace Education In The Classroom: Creating Effective Peace Education Programs. In Handbook On Peace Education, edited By G. Salomon, and E. Cairns, 223-240. New York: Psychology Press. 2010.
[13] Demir, S. An Overview of Peace Education in Turkey: Definitions, Difficulties, and Suggestions: A Qualitative Analysis. Educational Sciences: Theory \& Practice 11(4): 1727- 1745. 2011.

[14] Budak, Y. Training for Teachers in terms of Total Quality Management Service Training Needs And Approach to Program.” Milli Ĕ̈itim Dergisi 140. 1998.

[15] Dori, Y. J., and O. Herscovitz. A Case-Based Long-Term Professional Development Of Science Teachers. International Journal Of Science Education 27 (12):1413-1446. 2005.

[16] Sharma, S. R. Modern Teaching Strategies. New Delhi: Omsons Publications. 2000.

[17] Gökdere, M., and S. Cepni. A Study on the Assessment of the In-service Needs of the Science Teachers of Gifted Students: A Case for Science Art Center. Journal of Gazi Educational Faculty (24)2: 1-14. 2004.

[18] Seferoğlu, S.S. Qualifications, Standards and Information Continuing Vocational Training of Teachers in Light of Developments in Technology. Paper presented at the annual meeting Reflections on Education IX: National Symposium on Turkey's Teacher Training Dilemma, 204-217. 2009.

[19] Önen, F., H. Mertoğlu, M. Saka, and A. Gürdal. The Effects of In-Service Training on Teachers' Knowledge about Teaching Methods and Techniques: Öpyep Case. Journal of Kırşehir Education Faculty (KEFAD) 10: 3. 2009.

[20] Tekin, S., and S.Yaman. The Evaluation Scale of in-Service Education Program: The Development of Teachers' Form. Journal of Kırşehir Education Faculty (KEFAD) 9(3): 15-26. 2008

[21] Çakır, I. A Study For Science Teachers To Develop Their İnformation And Skills About Designing And Using İnstruction Sustaining Materials. Master's Thesis, Karadeniz Technical University. 2004.

[22] Kaya, A Developing a Laboratory Program for Physics Teachers' In-Service Needs: A Model For Suggestion." Doctoral Thesis, Karadeniz Technical University. 2003.

[23] Tekin, S. Development An Inservice Programme Concerning Conceptual Understanding and Concept Teaching For Chemistry Teachers And Investigation Of Its Influence In Practice. Doctoral Thesis, Karadeniz Technical University. 2004.

[24] Yalın, H. I., L. Hedges, and S. Özdemir. "In-Service Training Program Development Handbook: Turkey's Ministry of National Education." Education and Science 20 (102): 3-12. 1996.

[25] United Nations Educational Scientific and Cultural Organization. Learning the Way of Peace A Teachers' Guide to Peace Education. New Delhi: United Nations Educational, Scientic and Cultural Organization. 2001.

[26] National Council Of Educational Research And Training. Department of Educational Psychology and Foundations of Education National Council of Educational Research and Training. Sri Aurobindo Marg: New Delhi. 2006.

[27] Marthe, N.T. "Peace Education" Master Of Arts In Peace Education Curriculum Development, University For Peace. 2012. 
[28] Kester, K. "Developing Peace Education Programs: Beyond Ethnocentrism and Violence Peace Prints: South Asian." Journal of Peacebuilding 1(1): 1-28. 2008.

[29] Şenel, T. Investigating The Effectiveness Of İn-Service Course Programme For Science And Technology Teachers About Alternative Measurement And Assessment Technics. Master's Thesis, Karadeniz Technical University. 2008.

[30] Çınar, S. Development Of An In-Service Education Program Concerning Science-Technological-Society (Sts) Approach For Primary Teachers And İnvestigating İts Effectiveness." Doctoral Thesis, Karadeniz Technical University. 2011.

[31] Bjersted, A. Developing Preparedness For Peace: Objectives, Methods, Difficulties And Possibilities In Peace-Related Education. Peace Education Reports. Department Of Educational And Psychological Research, Lund University, Malmo: Sweden. Report No.18. 2003.

[32] Sağkal, A. Investigating The Effect Of Peace Education Program On The Sixth Grade Elementary Students' Aggressiveness Tendencies, Empathy Levels, And Perceptions Related To Peace. Master's Thesis, Dokuz Eylül University. 2011.

[33] Genç, G. O. Evaluating Peacebuilding İnitiatives Using Multiple Methodologies: Lessons Learned From A Greek Turkish Peace Education. Master's Thesis, Sabanc1 University. 2006.

[34] Türnüklü, A., T. Kaçmaz, S. Gürler, A. Kalender, F. Zengin, and B. Sevkin. The effects of conflict resolution and peer mediation education on students' empathy skills. Education and Science 34 (153): 15-24. 2009.

[35] Staub, E. From. Healing Past Wounds To The Development Of Inclusive Caring: Contents And Processes Of Peace Education. In Peace Education: The Concept, Principles, And Practices Around The World, edited by G. Salomon, and B. Nevo, 73-86. Mahwah, NJ: Lawrence Erlbaum Associates Publishers. 2002.

[36] Shapiro, J., J. Burgoon, C. Welker, and J.Clough. "Evaluation Of The Peacemakers Program: School - Based Violence Prevention For Students In Grades Four Through Eight." Psychology In The Schools 39(1): 87-100. 2002.

[37] Johnson, D., and R. Johnson. Implementing The Teaching Students To Be Peacemakers Program. Theory Into Practice 43(1): 68-79. 2004.

[38] Spears, S. C. "Freedom's children: Fifth graders perceptions of the effects of peace education in the form of Kingian nonviolence." Doctoral Dissertation, Available from Proquest Dissertations and Theses database, UMI No. 3135916. 2004.

[39] Tapan, C. Examination Of The Peace Education Programme's Effects On The Conflict Resolution Skills Of Students. Master's Thesis, Dokuz Eylül University. 2006.

[40] Kadivar, S. Toward A New Paradigm: Multicultural Peace Education." Doctoral Dissertation, Available from Proquest Dissertations and Theses database, UMI No. 3274991. 2007

[41] Walker, C. E. Teaching Students To Be Peacemakers: Implementing A Conflict Resolution And Peer Mediation Training İn A Minneapolis K - 6 Charter School. Doctoral Dissertation, Available from Proquest Dissertations and Theses database. UMI No. 3250168. 2007.
[42] Coşkuner, E. The Analysis Effect Of The Peace Education To Students Violence. Master's Thesis, Dokuz Eylül University. 2008 .

[43] Taber, N. Pedagogical Discourses Of Gender, Peace And Equality: Jane Addams Children's Book Awards. Journal of Peace Education 12(1):1-14. 2014.

[44] Açıkgöz, K.U. Active Learning (9th ed). İzmir: Biliş Publishing. 2007.

[45] Paykoç, F., and F. Schorn. Strengthening Inservice Education for Teachers and Educational Leaders in Türkiye (Final Report). Turkish National Education Development Project. Ankara: Ministry of National Education. 1993.

[46] Karaca, A. Primary School Teachers Opinions About In Service Training Programs (Mudurnu Case). Master's Thesis, Abant İzzet Baysal University 2010.

[47] Açıkalın, S. Private and Public Organizations In Service Training Barriers. Hacettepe University Journal of Education 6: 111-119. 1991.

[48] Yalın, H. I. Evaluation of In-Service Training Programme. National Education, 150. 2001.

[49] Turkey's Ministry of National Education (MEB- EARGED). Determination of the Classroom Teacher In-Service Training Needs. Ankara: MEB. 2008.

[50] Gökyer, N. The Problems And Priority Issues Of Teachers They Need In The Process In-Service Training. The Journal of Turkish Social Research 16: 2. 2012.

[51] Johnson, D., and R. Johnson. Reducing School Violence Through Conflict Resolution. Alexandria, Virginia: Association For Supervision and Curriculum Development. 1995.

[52] Bar-Tal D. The Elusive Nature of Peace Education. Journal of Social Issues 60 (2): 253- 271. 2004.

[53] Kamaraj, I., and A. Kerem. A Unıversal Overlook To 'Peace' Value In Early Childhood Period I. The Journal of Academic Social Science Studies 15:93-104. 2004.

[54] Deveci, H., F. Y1lmaz, and R. Karadağ. Pre-Service Teachers' Perceptions Of Peace Education. Eurasian Journal of Educational Research 30: 63-80. 2008.

[55] Harber, C., and N. Sakade. Schooling For Violence And Peace: How Does Peace Education Differ From 'Normal' Schooling. Journal Of Peace Education 6 (2): 171-187. 2009.

[56] Keskin, S., and Y. Keskin. Place of "Peace" as a Value in Primary School Social Studies Curricula and the Courses in the Scope of Social Studies in Turkish Republican Period. Journal of Values Education, 7(17): 69-92. 2009.

[57] Tutkun O.F., and Y. Aksoyalp. Dimensions of Teacher Training Curricula in The 21 st Century. Selçuk University Journal of Institute of Social Sciences 156 - 1692010.

[58] Pișkin, M., S. Öğülmüș, and M. Boysan. Creating a Safe School Environment: Teacher and Administrator Handbook. Ankara University. 2011

[59] Y1lmaz, O. 2011. Inclusive, Unprejudiced Leaders for Education: Teachers and Youth Workers for Peace Education Guide. Accessed March 2013. http://www.kayadcommunitycenter.com/kayad-life-tr.pdf 
[60] Sağkal, A., A. Türnüklü, and T. Totan. Empathy for Interpersonal Peace: Effects of Peace Education on Empathy Skills. Educational Sciences: Theory \& Practice 12 (2): 1447-1460. 2012.
[61] Önal G., and Z. Arsal. Peace Education In Prımary And Secondary School Curriculum. Abant İzzet Baysal University Journal Of Faculty Of Education 15(1):176-191. 2015.

[62] Karaman, K. Y. Opinions of University Students towards National and International Peace. Journal of Faculty of Educational Sciences 43(2): 27-49. 2010. 